Available online at website :

http://e-journal.adpgmiindonesia.com/index.php/jmie

JMIE: Journal of Madrasah Ibtidaiyah Education, 5(1), 2021, 141-155

\title{
PEMBELAJARAN DARING PADA MATA PELAJARAN MATEMATIKA SEKOLAH DASAR
}

\section{Shindy Lestari}

Universitas Islam Negeri Sunan Kalijaga Yogyakarta

E-mail: shindylestari4@gmail.com

Submit: 2 Agustus 2020, Revisi: 17 April 2021 Approve:19 Mei 2021

\begin{abstract}
Online learning in math subjects is very important to discuss so this study aims to evaluate online learning in math subjects. This study uses qualitative exploration case study method while sample technique is purposive sampling with a sample number of 45 students, 3 class teachers and 10 parents / guardians of grade V elementary school students in Pekanbaru. Data from research samples are collected through interviews and online questionnaires, so the results of this study explain the role of teachers and parents in the implementation of online learning in mathematics subjects, namely: 1) the role of teachers by creating a meaningful learning process, fun and adapted to the materials and characteristics of learners. 2) The role of parents is to guide, accompany, solve students' difficulties during home study, fostering students' learning interests. While the results of online learning evaluation in mathematics subjects show that students have difficulty focusing on understanding math materials and there are various obstacles such as on the network and the material taught is not discussed again by the teacher. As well as alternative solutions for the implementation of learning in math subjects can be done by providing contextual teaching materials, creating a communicative learning environment, using varied methods, teachers and parents / guardians of students must work together and coordinate online by providing information related to their child's development during online learning at home and give creative time to students doing useful activities at home as well as the role of teachers and parents / guardians of students by providing reinforcement, motivation to students as a form of increasing interest, spirit in conducting online learning activities in math subjects.
\end{abstract}

Keywords: Online Learning, Mathematics, Teacher Role, Parent Role

Pengutipan: Shindy Lestari. (2021). Pembelajaran Daring pada Mata Pelajaran Matematika Sekolah Dasar. JMIE: Journal of Madrasah Ibtidaiyah Education, 5(1), 2021, 141-155. jmie.v5i1.226.

Permalink/DOI: http:/ /dx.doi.org/10.32934/jmie.v5i1.226 


\section{PENDAHULUAN}

Pembelajaran merupakan usaha yang dilakukan dengan tujuan mencapai hasil yang lebih dari sebelumnya, dalam hal ini capaian suatu hasil tentu menggunakan strategi yang tepat, sebagaimana defenisi strategi pembelajaran merupakan cara yang digunakan guru melakukan aktivitas belajar mengajar dengan tujuan memberikan peserta didik perubahan pada ranah kognitif, afektif dan psikomotorik secara berkesinambungan. Menurut Azhar (2011) bahwa pembelajaran merupakan bentuk upaya yang dilakukan agar memperoleh informasi dan pengetahuan dalam suatu interaksi antara guru dengan siswa.

Fenomena wabah pandemi COVID-19 yang terjadi di Indonesia, sebagaimana termuat dalam SE Nomor 4 Tahun 2020 menjelaskan tentang pelaksanaan pembelajaran dilaksanakan dari rumah melalui pembelajaran menggunakan daring atau online. Proses pembelajaran di sekolah dasar dengan menggunakan pembelajaran daring tetap adanya pengawasan/bimbingan orang tua/wali. Menurut Isman (dalam Dewi, 2020) menyatakan bahwa pembelajaran daring dilakukan dengan memanfaatkan jaringan internet dalam kegiatan proses pembelajaran.

Sejalan pendapat Putria (2020) menjelaskan bahwa pembelajaran daring adalah kegiatan pembelajaran yang dikarenakan adanya jarak jauh sehingga memerlukan media komunikasi sekaligus internet. Pembelajaran daring juga memberikan keleluasaan waktu, kapanpun dan dimanapun kepada siswa untuk belajar. Beberapa aplikasi yang digunakan guru agar dapat berinteraksi dengan peserta didik dalam proses pembelajaran seperti video converence, room, google classroom, youtube, group whatsapp dan lain sebagainya untuk menunjang aktivitas pembelajaran.

Inovasi pendidikan dengan pembelajaran daring yang menggunakan berbagai aplikasi merupakan upaya yang dilakukan untuk menjawab tantangan perihal ketersediaan sumber pembelajaran yang bervariatif. Seperti yang diketahui bahwa pembelajaran daring termasuk aktivitas pendidikan formal yang diselenggarakan oleh sekolah dasar, dimana seorang guru sebagai instruktur untuk memandu peserta didik agar terlaksananya proses pembelajaran yang berada pada lokasi terpisah sehingga memerlukan media interaktif agar dapat saling terhubung yang salah satunya adalah pada mata pelajaran matematika di SD/MI.

Matematika sebagai ilmu yang universal sehingga dapat digunakan dalam kehidupan manusia dan dalam hal ini matematika juga mendasari dan menjadi faktor perkembangan teknologi modern serta mempunyai peran penting dalam berbagai disiplin dan memajukan daya pikir manusia, oleh karena itu matematika termuat dalam pembelajaran disetiap jenjang pendidikan.

Adanya problematika yang terjadi bahwa matematika merupakan pelajaran yang sulit dan tidak menarik bagi peserta didik, hal tersebut terjadi sebab sebagaimana berdasarkan teori Piaget (dalam Lestari, 2020) mengenai perkembangan kognitif (pengetahuan) peserta didik sekolah dasar berada pada tahapan operasioanal konkret yang berusia 7 - 12 tahun, Piaget berpendapat bahwa pada umumnya peserta didik sekolah dasar sulit memahami matematika yang bersifat abstrak.

Auliya (2016) menyatakan bahwa matematika dianggap sulit dikarenakan karakteristik matematika yang bersifat abstrak, logis, sistematis, terdapat simbol/lambang serta rumus yang membingungkan peserta didik. Selaras menurut Setiawan (2021) dalam penelitiannya bahwa 
permasalahan dalam pembelajaran matematika di sekolah dasar bahwa konsep matematika yang abstrak sering kali membuat guru kesulitan dalam menjelaskan materi kepada siswa secara virtual.

Melihat kondisi tersebut, maka perlu adanya perubahan dalam pembelajaran matematika selama daring berjalan. Oleh karena itu guru memiliki peran yang sangat penting untuk kreatif dalam mengembangkan pembelajaran, terkhusus penerapan sistem pembelajaran daring dapat menggunakan model, metode, strategi yang menyenangkan dan mengaitkan materi matematika dengan konteks dunia nyata sehingga dapat dipahami dengan baik oleh peserta didik.

Berdasarkan uraian tersebut, penting bagi guru untuk mampu menggunakan teknologi agar proses belajar mengajar berjalan dengan efektif dan efesien. Penelitian ini bertujuan untuk mengevaluasi pembelajaran daring pada mata pelajaran matematika serta memberikan solusi bagi guru. Sehingga dapat dijadikan referensi dan manfaat bagi pendidik dalam melakukan proses pembelajaran daring pada mata pelajaran matematika di sekolah dasar.

\section{METODE PENELITIAN}

Penelitian ini menggunakan metode studi kasus eksplorasi kualitatif untuk memperoleh data dan informasi mengenai evaluasi pembelajaran daring pada mata pelajaran matematika sekolah dasar. Menurut Guetterman (dalam Purwanto, et al 2020) ukuran sampel yang digunakan merupakan bentuk dari kekayaan informasi yang diperoleh, dalam penelitian ini responden sebanyak 45 orang siswa kelas V SD/MI di Pekanbaru. Metode pengumpulan data penelitian yaitu data primer dengan menggunakan google form sebagai media kuisioner online, dan sekaligus menggunakan data sekunder terdiri dari berbagai artikel yang dipublikasikan.

Sampel penelitian ditentukan dengan menggunakan teknik purposive sampling, dijelaskan oleh Bernard (dalam Purwanto, et al 2020) penelitian kualitatif dengan teknik purposive sampling tidak dibatasi jumlah respondennya, dengan syarat informasi yang diinginkan dapat menjawab permasalahan penelitian.

Perolehan data penelitian ini menggunakan kuisioner online yang diberikan kepada siswa dan wawancara kepada guru serta wali siswa yang dilakukan secara online melalui platform whatsapp, cara tersebut dimaksudkan untuk mendukung physical distancing guna mencegah penularan virus. Penelitian ini mewawancarai 3 orang guru kelas V SD/MI dan 10 wali siswa kelas V SD/MI yang berada di sekolah berbeda. Wawancara dilakukan bertujuan untuk menggali informasi dari subjek penelitian mengenai pembelajaran daring pada mata pelajaran matematika sekolah dasar. Teknik wawancara dilakukan sebab guru dan wali siswa berperan aktif dalam proses pembelajaran daring.

Teknik analisis data yang didapatkan dari subjek penelitian menurut Miles dan Huberman yaitu di mana peneliti melakukan langkah-langkah, antara lain: pertama, tahap reduksi data dengan melakukan penyederhanaan, data yang muncul dari lapangan. Pada penelitian ini reduksi data dilakukan dengan menyederhanakan hasil dari kuisioner online dan wawancara dari sampel penelitian. Kedua, sekumpulan informasi yang disajikan dapat dilakukan penarikan simpulan dan pengambilan tindakan. Ketiga, tahap simpulan dan verifikasi dengan membuat 
kesimpulan terhadap penafsiran dan evaluasi. Sedangkan tahap terakhir yaitu membuat kesimpulan dari hasil analisis data dengan melakukan pendeskripsian yang telah dikumpulkan melalui kuisioner online dan wawancara dari data yang telah direduksi atau yang disebut dengan data yang sudah disederhanakan dan relevan dengan tujuan penelitian.

\section{HASIL PENELITIAN}

\section{Pelaksaan Pembelajaran Daring Mata Pelajaran Matematika}

Penerapan pembelajaran matematika sekolah dasar di kelas rendah (I, II, III) diintegrasikan dengan pembelajaran tematik, sedangkan di kelas tinggi (IV, V, VI) pembelajaran matematika terpisah dari tematik, hal tersebut bertujuan agar penguasaan kompetensi matematika dapat mendalam. Dengan demikian perolehan hasil penelitian yang dilakukan dengan mewawancarai 3 orang guru kelas V SD/MI bertujuan untuk mengetahui pelaksanaan pembelajaran daring pada mata pelajaran matematika kelas V sekolah dasar, sebagai berikut:

Pertama, tahapan pendahuluan yaitu guru memberitahu kepada seluruh siswa mengenai materi yang akan dipelajari keesokan harinya. Proses pembelajaran matematika secara daring dapat dilakukan dengan memanfaatkan berbagai platform yang disesuaikan dengan kesanggupan siswa serta materi ajar matematika. Ketika proses pembelajaran matematika berlangsung, guru mengulas materi yang sebelumnya sudah pernah dipelajari dengan menyampaikan konsep secara kontekstual, hal tersebut dilakukan untuk membelajarkan siswa berpikir konkret menuju berpikir abstrak. Setelah siswa memahami konsep yang dibangun dari pengetahuan awalnya, maka selanjutnya guru menyampaikan tujuan materi ajar agar siswa dapat mencapai tujuan pembelajaran tersebut.

Kedua, tahapan inti yaitu guru memberikan media pembelajaran yang menarik dan disesuaikan dengan materi ajar matematika serta karakteristik siswa. Setelah siswa dapat memahami materi melalui media pembelajaran, selanjutnya guru memberi contoh-contoh soal, hal tersebut bertujuan agar konsep matematika dapat diaplikasikan untuk menyelesaikan soalsoal matematika.

Menyampaikan materi matematika dapat dilakukan dengan menggunakan media visual, audio dan audio visual, hal tersebut dilakukan agar siswa dapat melihat serta mendengar materi yang sampaikan oleh guru. Selain dari pada itu, penjelasan materi dan pemberian latihan-latihan soal dapat dipadukan dengan berbagai kegiatan atau game agar terciptanya pembelajaran daring pada mata pelajaran matematika yang menarik serta menyenangkan. Kemudian siswa diminta untuk mengirimkan hasil kerjanya bisa menggunakan platform whatsapp, google classroom, edmodo dan lain sebagainya sesuai dengan kesepakatan bersama.

Ketiga, tahapan penutup yaitu guru melakukan refleksi serta meminta siswa untuk menyimpulkan materi matematika dan diperkuat dengan apresiasi atas kegiatan yang siswa lakukan selama proses pembelajaran daring. Hal tersebut bertujuan sebagai evaluasi serta meningkatkan dan memperkuat motivasi siswa dalam belajar matematika.

Hasil penelitian menunjukkan bahwa pentingnya guru menciptakan proses pembelajaran daring khususnya pada mata pelajaran matematika yang bermakna, menyenangkan 
dan disesuaikan dengan materi serta karakteristik peserta didik. Hal ini selaras menurut Wiryanto (2020) dalam penelitiannya bahwa pembelajaran matematika dengan sistem daring menuntut guru untuk memberikan penjelasan materi dan tugas melalui group whatsapp. Selanjutnya guru memberikan durasi waktu untuk siswa mengerjakan tugas tersebut yang bertujuan agar siswa dapat mencapai suatu kompetensi yang diharapkan. Namun, tidak mengkhususkan hanya melalui whatsapp, tetapi guru juga terkadang melakukan pembelajaran daring melalui berbagai aplikasi jika mendukung. Penggunaan aplikasi tatap muka langsung seperti zoom atau google classroom dalam pembelajaran dapat memberikan pengalaman belajar yang lebih menyenangkan bagi peserta didik karena dapat mendengar langsung penjelasan materi yang disampaikan oleh gurunya.

Pelaksanaan pembelajaran daring pada mata pelajaran matematika tidak menutup kemungkinan bahwa terdapat berbagai kendala yang diantaranya pemahaman siswa terhadap suatu materi kurang mendalam, siswa sulit fokus dikarenakan terdapat situasi kondisi tidak kondusif, kuota internet terbatas, jaringan internet yang tidak stabil dan juga terdapat gangguan dari berbagai hal lainnya.

Sedangkan kelebihan dari pembelajaran daring tersebut tidak terbatas oleh tempat yang dapat dilakukan dengan belajar di ruang tamu, kamar, dan sebagainya serta waktu belajar pada pagi, siang, sore atau malam, sehingga mengatasi permasalahan mengenai jarak dan cakupan area yang luas. Hal ini sejalan dengan penelitian yang dilakukan oleh Sari (2015) bahwa kelebihan dari pembelajaran daring yaitu tercipatnya suasana belajar yang baru sehingga menumbuhkan antusias peserta didik dalam belajar.

\section{Peran Orang Tua Dalam Pembelajaran Daring Pada Mata Pelajaran Matematika}

Proses pembelajaran jarak jauh menuntut peran orang tua untuk memantau kegiatan siswa di rumah selama penerapan pembelajaran daring pada mata pelajaran matematika. Diperoleh hasil wawancara kepada 10 orang tua/wali siswa kelas V di Pekanbaru, yakni dapat di lihat pada tabel berikut:

1. Apakah Bapak/Ibu menemani dan membimbing anak selama pembelajaran daring pada mata pelajaran matematika?

Tabel 1. Peran Orang Tua Menemani dan Membimbing

\begin{tabular}{lccc}
\hline No & Keterangan & Frekuensi & Persentase \\
\hline 1 & Setuju & 4 & $40 \%$ \\
2 & Kadang-Kadang & 3 & $30 \%$ \\
3 & Tidak Setuju & 3 & $30 \%$ \\
\hline
\end{tabular}

Dari tabel di atas terlihat bahwa orang tua/wali menemani dan membimbing siswa selama pembelajaran daring pada mata pelajaran matematika yang menyatakan setuju sebesar 40\% dan kadang-kadang 30\% sedangkan tidak setuju 30\%. Dari hasil wawancara diperoleh informasi bahwa orang tua yang menyatakan setuju yaitu bekerja sebagai ibu rumah tangga dan yang menyatakan kadang-kadang merupakan orang tua yang mengajarkan anaknya untuk mandiri namun tetap dalam pengawasan, sedangkan orang tua yang menjawab tidak setuju yaitu 
kedua orang tua yang bekerja, sehingga selama pembelajaran daring matematika anak ditemani oleh saudaranya.

Berdasarkan hasil penelitian di atas, bahwa sangat penting peran orang tua dalam membimbing anak selama melaksanakan pembelajaran daring. Selaras menurut Wardhani dan Krisnani (2020) yang menyatakan bahwa orang tua wajib menyediakan waktu luang yang cukup ekstra agar dapat mengawasi, mendampingi anak dalam melakukan sekolah online. Sehingga pembelajaran daring khususnya mata pelajaran matematika dapat berjalan dengan baik.

\section{Apa kesulitan yang Bapak/Ibu rasakan selama mendampingi siswa belajar pembelajaran daring pada mata pelajaran matematika?}

Tabel 2. Kendala Daring Mata Pelajaran Matematika

\begin{tabular}{cccc}
\hline No & Keterangan & Frekuensi & Persentase \\
\hline 1 & Tidak Mengerti Materi & 7 & $70 \%$ \\
2 & Tugas Terlalu Banyak & 3 & $30 \%$ \\
\hline
\end{tabular}

Berdasarkan tabel di atas, menunjukkan bahwa kesulitan yang dialami atau dirasakan orang tua/wali siswa selama mendampingi pembelajaran daring pada mata pelajaran matematika diperoleh persentase sebesar $70 \%$ yang menyatakan tidak mengerti terhadap materi yang diajarkan dan sebesar 30\% menjawab tugas mata pelajaran matematika yang diberikan terlalu banyak. Dari hasil wawancara diperoleh informasi bahwa orang tua yang menyatakan tidak mengerti terhadap materi matematika dikarenakan latar belakang pendidikan dan merasa bahwa materi sulit untuk dipahami apabila hanya disampaikan guru menggunakan audio visual tanpa adanya penjelasan materi yang lebih rinci.

Orang tua yang menjawab tugas terlalu banyak disebabkan guru memberikan tugas setiap adanya pembelajaran matematika, tanpa adanya penjelasan kembali mengenai tugas yang sudah dikerjakan, artinya tidak adanya penguat atas hasil kerja, sehingga siswa merasa jenuh dan bosan setiap diberi tugas matematika.

Hasil penelitian ini senada dengan yang diungkapkan oleh Wiryanto (2020) bahwa siswa merasa jenuh disebabkan pembelajaran hanya berfokus kepada tugas, serta saat guru menjelaskan melalui aplikasi tatap muka sering terjadi gangguan signal sehingga materi yang disampaikan menjadi tidak jelas. Sependapat menurut hasil penelitian di lapangan yang dilakukan oleh Cahyati \& Kusumah (2020) menunjukkan bahwa kurangnya pemahaman orang tua terhadap materi yang diberikan sehingga menyulitkan orang tua menyampaikan kepada anaknya.

\section{Bagaimana cara Bapak/Ibu mengatasi kendala selama pembelajaran daring pada mata pelajaran matematika?}

Tabel 3. Mengatasi Kendala Daring Mata Pelajaran Matematika

\begin{tabular}{lccc}
\hline No & Keterangan & Frekuensi & Persentase \\
\hline 1 & Searching Internet & 4 & $40 \%$ \\
2 & Bertanya Kepada Orang & & \\
\hline
\end{tabular}




\begin{tabular}{ccc}
\hline Yang Paham Terhadap & 5 & $50 \%$ \\
Materi Matematika & & \\
Membantu Anak & & $10 \%$ \\
\hline
\end{tabular}

Dari tabel di atas, upaya dalam mengatasi kendala pembelajaran daring pada mata pelajaran matematika diperoleh hasil persentase sebesar $40 \%$ untuk searching internet dan bertanya kepada orang yang paham terhadap materi matematika sebesar 50\% sedangkan membantu anak mengerjakan tugas semampunya sebesar 10\%. Dari hasil wawancara diperoleh informasi bahwa ketika guru memberi tugas dan materi yang dijelaskan sulit untuk dimengerti atau dipahami siswa, upaya orang tua mencari informasi terkait tugas di internet bahkan bertanya kepada saudara atau orang-orang yang mengetahui mengenai materi matematika kelas $\mathrm{V}$ SD/MI. Selain dari pada itu, ada juga orang tua yang membantu siswa mengerjakan tugas semampunya, hal ini dikarenakan kurangnya kecakapan orang tua dalam menggunakan teknologi dan kesulitan memahami materi.

Selaras menurut Islami (2021) menyatakan dalam penelitiannya bahwa anak dan orang tua mengalami kesulitan terhadap materi. Sehingga orang tua mencari informasi lain melalui internet dan tidak selalu mengandalkan materi yang diberikan oleh guru. Namun, kendala tersebut dapat diatasi menurut Wardhani dan Krisnani (2020) apabila menemui kesulitan, segera konfirmasi guru yang bersangkutan, sebab dalam perlaksanaan pembelajaran daring ini, pemahaman anak dalam menguasai materi sangat dipengaruhi oleh bimbingan orang tua.

\section{Bagaimana upaya Bapak/Ibu menumbubkan minat belajar siswa selama pembelajaran daring pada mata pelajaran matematika?}

Tabel 4. Menumbuhkan Minat Belajar Matematika

\begin{tabular}{llcc}
\hline No & Keterangan & Frekuensi & Persentase \\
\hline 1 & Mengapresiasi & 2 & $20 \%$ \\
2 & Memfasilitasi & 2 & $20 \%$ \\
3 & Mendampingi & 4 & $40 \%$ \\
4 & Memotivasi & 2 & $20 \%$ \\
\hline
\end{tabular}

Pada tabel di atas, upaya orang tua/wali siswa untuk menumbuhkan minat belajar siswa selama pembelajaran daring pada mata pelajaran matematika diperoleh hasil persentase sebesar $20 \%$ yang melakukan upaya dengan mengapresiasi aktivitas siswa, 20\% orang tua memfasilitasi, $40 \%$ orang tua mendampingi siswa serta memberikan motivasi sebesar $20 \%$. Orang tua berperan penting menumbuhkan minat belajar siswa sekolah dasar khususnya pada mata pelajaran matematika, sebab upaya menumbuhkan minat tersebut akan berdampak pada aktivitas dan hasil belajar siswa. 
Perolehan hasil penelitian ini seleras menurut Safitri (202) menyatakan bahwa orang tua berperan dalam meningkatkan minat belajar siswa seperti pemberian bimbingan, nasihat, pengawasan serta memfasilitasi, hal tersebut merupakan faktor pendukung agar siswa melakukan kegiatan belajar dengan baik.

\section{Evaluasi Pembelajaran Daring Mata Pelajaran Matematika}

Penelitian ini bertujuan sebagai bahan evaluasi pembelajaran daring pada mata pelajaran matematika di sekolah dasar sehingga dapat memberikan solusi dalam pelaksaan pembelajaran daring agar berjalan dengan efektif dan efesien. Pengumpulan data pada penelitian ini menggunakan kuisioner online berupa google form yang terdiri dari lima pertanyaan, Hasil perolehan persentase dari 45 responden peserta didik sekolah dasar, dapat di lihat pada tabel berikut:

1. Apakah ananda (sebagai siswa) merasa (mudah, cukup, sulit) untuk mengerti dan memahami materiyang diajarkan guru pada mata pelajaran matematika?

Tabel 5. Tingkat Pemahaman Siswa

\begin{tabular}{llc}
\hline No & Keterangan & Persentase \\
\hline 1 & Mudah & $18 \%$ \\
2 & Cukup & $42 \%$ \\
3 & Sulit & $40 \%$ \\
\hline
\end{tabular}

Hasil penelitian dari google form menunjukkan bahwa tingkat pemahaman dengan menggunakan sistem pembelajaran daring yaitu terdapat peserta didik yang merasa mudah mengerti dan memahami materi matematika disampaikan guru diperoleh persentase yakni sebesar 18\%, sedangkan peserta didik yang merasa cukup yakni sebesar 42\%, dan peserta didik yang merasa kesulitan yakni sebesar $40 \%$.

2. Apakah tugas matematika yang diberikan, kemudian dijelaskan kembali oleh guru secara ringkas?

Tabel 6. Penjelasan Kembali Tugas Matematika

\begin{tabular}{lcc}
\hline No & Keterangan & Persentase \\
\hline 1 & Ya & $76 \%$ \\
2 & Tidak & $24 \%$ \\
\hline
\end{tabular}

Kegiatan pembelajaran masa pandemi COVID-19 yaitu terdapat kebijakan pemerintah tidak mengharuskan bagi pendidik untuk memberikan materi hingga selesai namun harus sesuai dengan ketentuan yang ada dibuku guru dan siswa, oleh karena itu pendidik harus tetap melakukan pembelajaran setiap hari nya menurut Reksy selaku wali kelas V di salah satu sekolah dasar Negeri Pekanbaru. Hasil persentase dari google form yang disebarkan kepada responden diperoleh $76 \%$ peserta didik yang merasa bahwa guru mengulang kembali materi dari tugas 
matematika, dan 24\% peserta didik merasa guru tidak mengulang materi dari tugas yang diberikan.

3. Seberapa tertarikah ananda (sebagai siswa) mengikuti pembelajaran daring pada mata pelajaran matematika?

Tabel 7. Ketertarikan Pembelajaran Daring Mata Pelajaran Matematika

\begin{tabular}{ccc}
\hline No & Keterangan & Persentase \\
\hline 1 & Sangat Tertarik & $25 \%$ \\
2 & Cukup Tertarik & $53 \%$ \\
3 & Tidak Tertarik & $22 \%$ \\
\hline
\end{tabular}

Pembelajaran daring pada jenjang sekolah dasar merupakan hal baru yang harus diterapkan pada masa pandemi saat ini, hasil persentase menunjukkan bahwa terdapat 25\% peserta didik merasa tertarik dengan pembelajaran daring, sedangkan terdapat $53 \%$ peserta didik yang merasa cukup tertarik dan $22 \%$ peserta didik merasa tidak tertarik. Pada hasil persentase responden, terdapat faktor pendukung dan juga penghambat sehingga jawaban responden bervariatif sesuai dengan yang dirasakan terkait dengan ketertarikan penerapan pembelajaran daring pada mata pelajaran matematika. Kurangnya meninat siswa sebagaimana menurut Anggianita dkk (2020) dalam penelitiannya disebabkan bahwa pembelajaran hanya dilakukan dengan menggunakan grup di platform yang dominan berisi teks. Sehingga proses pembelajaran mata pelajaran matematika menjadikan lingkungan belajar yang monoton.

\section{Media apakah yang digunakan guru saat menjelaskan materi pada mata pelajaran matematika?}

Tabel 8. Media Pembelajaran Daring Mata Pelajaran Matematika

\begin{tabular}{lcc}
\hline No & Keterangan & Persentase \\
\hline 1 & Whatsaap (WA) & $62 \%$ \\
2 & Google Classroom & $7 \%$ \\
3 & Zoom & $9 \%$ \\
4 & Youtube & $22 \%$ \\
\hline
\end{tabular}

Pembelajaran daring dapat dilakukan dengan menggunakan berbagai platform atau aplikasi online yang tentunya dipilih sesuai dengan kesepakatan pendidik dan peserta didik dengan mempertimbangkan segala aspek agar terlaksananya proses pembelajaran dengan baik. Di jenjang sekolah dasar terkhusus pada mata pelajaran matematika, diperoleh hasil persentase menunjukkan media dalam proses pembelajaran ialah terdapat $62 \%$ menggunakan whatsapp group, $7 \%$ google class room, $9 \%$ zoom dan $22 \%$ youtube.

Persentase penggunaan whatsapp group lebih tinggi dari pada aplikasi yang lain, hal ini dikarenakan pendidik memperhatikan segala aspek terutama dari tingkat ekonomi dan latar belakang orang tua/wali peserta didik yang terkendala pada dana kuota internet sekaligus 
pemahaman terhadap pengunaan platform. Selaras dengan penelitian Mustakim (2020) menyatakan bahwa secara umum untuk harga mengakses internet relatif mahal dan menurut Rosarians et al, Harususilo (dalam Daheri et al, 2020) hasil survei pada jenjang sekolah dasar menunjukkan 100\% belajar daring hanya menggunakan media whatsapp group.

5. Apakah kendala yang ananda (sebagai siswa) hadapi selama pembelajaran daring pada mata pelajaran matematika berlangsung?

Tabel 9. Kendala Pembelajaran Daring Mata Pelajaran Matematika

\begin{tabular}{lcc}
\hline No & Keterangan & Persentase \\
\hline 1 & Sulit Fokus & $62 \%$ \\
2 & Jaringan Tidak Stabil & $31 \%$ \\
3 & Aplikasi Rumit & $7 \%$ \\
\hline
\end{tabular}

Permasalahan yang dihadapi peserta didik dalam pembelajaran daring pada mata pelajaran matematika menunjukkan hasil pesentase terbesar yakni $62 \%$ yaitu peserta didik merasa sulit fokus dan 31\% peserta didik mengalami jaringan internet yang tidak stabil, serta 7\% peserta didik mengalami kesulitan dalam penggunaan platform. Hal ini selaras dengan penelitian yang dilakukan Mustakim (2020) bahwa pembelajaran daring memiliki berbagai faktor penghambat yaitu terjadi pada jaringan internet yang tidak stabil dan platform yang rumit, dengan demikian membuat peserta didik tetap lebih senang dalam proses pembelajaran tatap muka secara langsung.

\section{PEMBAHASAN PENELITIAN}

Pada masa dewasa ini inovasi pembelajaran dengan memanfaatkan teknologi informasi yang terhubung jaringan internet sebagai media penunjang proses belajar mengajar. Namun, terjadinya perubahan secara tiba-tiba yang disebabkan adanya virus ini tidak dapat dipungkiri membuat pendidik, peserta didik maupun orang tua/wali merasa kaget dengan pengalihan pembelajaran dari tatap muka menjadi daring. Penggunaan teknologi yang dilakukan dalam proses pembelajaran menuntut guru harus mampu dalam memberikan ruang gerak bagi siswa agar dapat bereksplorasi serta memudahkan interaksi dan berkolaborasi antar siswa maupun siswa dengan guru.

Pembelajaran konsep dan struktur materi matematika perlu diawali dengan memberikan pengenalan permasalahan secara kontekstual dan membimbing peserta didik secara bertahap. Dengan demikian sangat penting meningkatkan keefektifan dan memaksimalkan pembelajaran matematika secara daring yang memanfaatkan teknologi serta alat peraga ataupun media sebagai penunjang dalam pelaksaannya (Wiryanto, 2020).

Pembelajaran secara daring pada mata pelajaran matematika dengan menggunakan media yang terhubung jaringan internet tidak sepenuhnya dapat memberikan dampak baik bagi seluruh pihak baik pendidik, peserta didik maupun orang tua/wali. Dalam hal ini faktor yang 
mempengaruhi keberhasilan siswa dalam melaksanakan pembelajaran secara daring diantaranya yaitu karakteristik siswa dan lingkungannya.

Faktor lingkungan yang paling penting adalah kesiapan orang tua dalam berperan untuk membimbing siswa melakukan pembelajaran secara daring serta pemerataan akses internet diberbagai daerah di Indonesia. Sedangkan karakteristik siswa yang dapat mempengaruhi keberhasilan pembelajaran daring yaitu guru harus memperhatikan tahapan pemahaman siswa berdasarkan perkembangannya, oleh karena itu, akan timbul semangat serta antusias siswa dalam mengikuti proses pembelajaran, namun jika siswa memiliki semangat dan antusias yang rendah maka hasilnyapun akan kurang maksimal.

Pembelajaran matematika SD/MI bertujuan untuk membekali peserta didik memiliki kemampuan matematisasi yang dapat diimplementasikan dalam kehidupan sehari-hari serta memecahkan masalah. Selain dari pada itu, matematika sebagai alat untuk kehidupan, mengomunikasikan gagasan melalui simbol matematika sekaligus kemampuan bernalar, berpikir secara kritis dan kreatif (Nurmalita \& Hardjono, 2020).

Peran guru dalam menjelaskan materi serta pemberian tugas matematika dilakukan dengan pemantauan serta pendampingan oleh guru melalui aplikasi yang disepakati seperti group whatsapp, google classroom dan lain-lain, kemudian guru juga bekerja dari rumah dengan berkoordinasi bersama orang tua yang dapat dilakukan dengan membagikan foto kegiatan belajar siswa selama dirumah (Sari dkk, 2021).

Guru berperan semaksimal mungkin agar pembelajaran daring mata pelajaran matematika dapat terlaksana dengan baik, sehingga tujuan tercapai. Namun, tidak menutup kemungkinan bahwa terdapat berbagai permasalahan dalam pelaksaan pembelajaran daring pada mata pelajaran matematika di sekolah dasar, seperti: ganguan signal internet, kurangnya pendampingan orang tua, kurangnya interaksi antara guru dan siswa, hal ini akan berdampak pada rendahnya hasil belajar dan pemahaman terhadap materi matematika serta siswa termotivasi untuk belajar matematika.

Permasalahan terjadi disebabkan konsep matematika yang abstrak sering kali membuat guru kesulitan dalam menjelaskan kepada siswa secara virtual. Maka perlu adanya suatu perubahan dengan mengaitkan materi matematika dan disampaikan melalui contoh-contoh pada kehidupan sehari-hari di rumah dengan cara melibatkan orang tua dalam menyelesaikan tugas yang diberikan kepada siswa (Setiawan, 2021).

Pembelajaran daring pada mata pelajaran matematika dapat menggunakan berbagai aplikasi belajar yang tersedia agar pembelajaran tidak monoton, seperti: memberikan media pembelajaran yakni audio, visual maupun audio visual yang guru buat sendiri atau yang dapat di download dari aplikasi youtube. Media pembelajaran berfungsi sebagai pendukung penyampaian materi matematika dalam pembelajaran daring akan mudah dipahami atau dimengerti oleh siswa serta orang tua yang mendampingi siswa.

Peran orang tua sangat penting dalam pembelajaran daring khususnya matematika yaitu dengan mendampingi siswa, orang tua sebagai pemberi semangat, memfasilitasi kebutuhan siswa dan menjadi tempat berdiskusi serta bertanya, melihat dan mengembangkan bakat siswa sekaligus menciptakan lingkungan yang kondusif untuk belajar (Iftitah \& Anawaty, 2020). Hal 
tersebut bertujuan agar materi matematika yang bersifat abstrak mampu dipahami oleh siswa ketika lingkungan belajarnya dirumah kondusif dan mendapatkan perhatian, bimbingan serta arahan dari guru dan orang tuanya.

\section{Solusi Alternatif Pelaksanaan Pembelajaran Daring Pada Mata Pelajaran Matematika Sekolah Dasar}

Pendidik dituntut mampu menggunakan, memanfaatkan TIK secara efektif dan efesien agar terciptanya pembelajaran yang menarik, bermakna dan menyenangkan bagi peserta didik, misalnya dengan membuat video dalam penyampaian materi berupa animasi yang unik, game matematika yang menarik, sehingga dapat meningkatkan minat dan memotivasi peserta didik dalam proses pembelajaran matematika menggunakan sistem pembelajaran daring sebab peserta didik akan tertarik apabila belajar dengan mengaitkan sesuatu yang dekat berdasarkan kehidupan sehari-hari, pengalaman dan juga adanya hal baru.

Dari hasil penelitian yang dilakukan, terdapat beberapa solusi pembelajaran daring mata pelajaran matematika, antara lain: Pertama, guru memberikan materi ajar secara kontekstual yang disampaikan menggunakan media berupa visual, audio maupun video dalam pembelajaran daring sekaligus disesuaikan dengan kemampuan siswa sekolah dasar.

Kedua, pembelajaran daring mata pelajaran matematika dilakukan dengan menciptakan lingkungan belajar yang komunikatif yaitu di mana siswa dapat berinteraksi dengan guru menggunakan berbagai platform seperti google classroom, video converence, zoom, whatsapp, edmodo dan lainnya agar dapat menciptakan proses pembelajaran daring yang tidak monoton.

Ketiga, guru dapat melakukan cara yang beragam selama melaksanakan proses pembelajaran di rumah, seperti menggunakan metode ceramah online, membuat video di kelas kemudian pendidik menguploadnya ke whatsapp group dan pendidik yang memanfaatkan kontenkonten gratis dari berbagai sumber seperti pada aplikasi youtube.

Keempat, guru dan orang tua/wali peserta didik dituntut untuk saling berkerja sama dan berkoordinasi secara online, dalam hal ini orang tua/wali harus ikut andil dengan aktif menanyakan kepada guru perihal materi ajar dan tugas yang harus dikerjakan, sekaligus juga sebaliknya bagi orang tua saling memberitahukan mengenai aktivitas yang akan dilakukan dalam proses pembelajaran termasuk tugas dan perkembangan peserta didik selama belajar di rumah, sehingga guru dapat memberikan arahan mengenai penerapan pembelajaran daring mata pelajaran matematika pada masa pandemi saat ini.

Kelima, guru selalu memberikan pengertian kepada orang tua mengenai pembelajaran daring/jarak jauh yang dilakukan di rumah, dalam hal ini tentu tidak menutup kemungkinan akan membuat peserta didik merasa jenuh atau bosan, oleh karena itu sangat penting untuk memberikan waktu berkreasi dengan melakukan aktivitas bermanfaat di rumah, seperti melakukan piknik di perkarangan rumah, berolah raga, berkebun dan lain sebagainya serta tidak adanya tempat perkumpulan yang memicu penularan virus.

Keenam, perihal orang tua/wali peserta didik yang sibuk bekerja, yaitu pendidik memberikan kelonggaran waktu agar dapat berdiskusi bersama karena peran orang tua/wali 
sangat penting dalam membimbing dan juga mengawasi peserta didik selama kegiatan proses pembelajaran, dan juga orang tua harus selalu memberikan informasi terkait dengan perkembangan anaknya, sehingga guru dapat memberikan penguatan, motivasi kepada peserta didik sebagai bentuk meningkatkan semangatnya dalam melakukan kegiatan pembelajaran daring.

\section{SIMPULAN}

Berdasarkan uraian di atas, diperoleh beberapa kesimpulan sebagai jawaban dari pertanyaan penelitian bahwa proses pembelajaran daring pada mata pelajaran matematika masih belum optimal disebabkan berbagai faktor terjadi yakni lingkungan dan karakteristik peserta didik. Dalam hal ini faktor lingkungan berupa peran guru, orang tua, sarana prasarana yang memadai seperti media elektronik, jaringan internet, sedangkn faktor karakteristik peserta didik yaitu pada perkembangan dan pemahaman.

Pembelajaran daring pada mata pelajaran matematika yang bersifat abstrak memerlukan kerja sama antara guru dan orang tua/wali. Peran guru dalam menyampaikan dan menjelaskan materi serta memberikan tugas harus disesuaikan dengan perkembangan dan pemahaman siswa, seperti: mengaitkan materi secara kontekstual serta penggunaan media pembelajaran yang bervariasi yakni audio, visual dan audio visual. Aplikasi dalam pembelajaran daring dapat menggunakan group whatsapp, google classroom, edmodo dan lain sebagainya. Selain dari pada itu, orang tua juga berperan dalam memfasilitasi, membimbing, mengarahkan, mengawasi siswa selama pembelajaran daring dengan memberi motivasi, perhatian dan memperhatikan minat serta bakat siswa agar aktivitas pembelajaran matematika dapat berjalan dengan efektif dan efesien, sehingga berdampak pada hasil belajar yang baik.

\section{DAFTAR PUSTAKA}

Anggianita, S., Yusnira., \& Rizal, M. S. (2020). Persepsi Guru terhadap Pembelajaran Daring di Sekolah Dasar Negeri 013 Kumantan. Journal of Education Research, 1(2), 177-182.

Auliya, R. N. (2016). Kecemasan Matematika Dan Pemahaman." Formatif: Jurnal Ilmiah Pendidikan MIPA, 6(20), 12-22.

Arsyad, A. Media Pembelajaran. (2011). Jakarta: Rajawali Pers.

Cahyati, N., \& Kusumah, R. (2020). Peran Orang Tua Dalam Menerapkan Pembelajaran Di Rumah Saat Pandemi Covid 19. Jurnal Golden Age, 4(1), 152 - 159.

Daheri, M., Juliana, D., \& Amda, A. D. (2020). Efektifitas WhatsApp Sebagau Media Belajar Daring. Jurnal Basicedu Research \& Learning in Elementary School, 4(4), 775-783.

Dewi, W, A. F. (2020). Dampak COVI-19 Terhadap Implementasi Pembelajaran Daring Di Sekolah Dasar. Edukatif: Jurnal Ilmiah Pendidikan, 2(1), 55-61. 
Iftitah, S. L., \& Anawaty, M. F. (2020). Peran Orang Tua Dalam Mendampingi Anak Di Rumah Selama Pandemi Covid-19. JCE (Journal of Childhood Education), 4(2), 71-81.

Islami, A. O. (2021). Peran Orang Tua Dalam Pembelajaran Daring kelas III MI Mi'Rojul Ulum Jotangan Kecamatan Mojosari Kabupaten Mojokerto. (Skripsi: UIN Sunan Ampel Surabaya)

Lestari, S. (2020. Analisis Materi Pokok Matematika Kelas III MI / SD. El-Ibtidaiy: Journal of Primary Education, 3(1), 1-17.

Mustakim. (2020). Efektivitas Pembelajaran Daring Menggunakan Media Online Selama Pandemi Covid-19 Pada Mata Pelajaran Matematika The Effectiveness Of ELearning Using Online Media During The Covid-19 Pandemic In Mathematics. Al Asma: Journal of Islamic Education, 2(1), 1-12.

Nurmalita, R. A., \& Hardjono, N. (2020). Efektifitas Penggunaan Pendekatan Pendidikan Matematika Realistik (PMR) Untuk Meningkatkan Kemampuan Berpikir Kritis Siswa Sekolah Dasar. Jurnal Pendidikan Dan Konseling (JPDK), 1(2), 54-62.

Purwanto, A., Pramono, R., Asbari, M., Santoso, P. B., Wijayanti, L. M., Choi, C. H., \& Putri, R. S. (2020). Studi Eksploratif Dampak Pandemi COVID-19 Terhadap Proses Pembelajaran Online Di Sekolah Dasar. EduPsyCouns: Journal of Education, Psychology and Counseling, 2(1), 1-12.

Putria, H., Maulana, L. H., \& Uswatun, D. A. (2020). Analisis Proses Pembelajaran Dalam Jaringan (DARING) Masa Pandemi COVID-19 Pada Guru Sekolah Dasar. BASICEDU, 4(4), 861-872.

Safitri, L. K. (2020). Peran Orang Tua Dalam Meningkatkan Minat Belajar Anak Pada Pembelajaran Online Di SD Negeri 5 Metro Pusat. (Skripsi: IAIN Metro).

Sari, P. (2015). Memotivasi Belajar Dengan Menggunakan E-Learning. Jurnal Ummul Quro, 6(2), $20-35$.

Sari, R. P., Tusyantari, N. B., \& Suswandari, M. (2021). Dampak Pembelajaran Daring Bagi Siswa Sekolah Dasar Selama Covid-19. Prima Magistra: Jumal Ilmiah Kependidikan, 2(1), 9-15.

Setiawan, W. (2021) Matematika Pada Sekolah Dasar Di Era Pandemi. Majamath: Jurnal Matematika dan Pendidikan Matematika, 4(1), 12-22. 
Surat Edaran Nomor 4 Tahun 2020 Tentang Pelaksanaan Kebijakan Pendidikan Dalam Masa Darurat Penyebaran Corona Virus Disease (COVID-19) Pada Satuan Pendidikan. (2020). http://pgdikmen.kemdikbud.go.id/read-news/surat-edaran-mendikbudnomor-4-tahun-2020.

Wardhani, T. Z. Y., \& Krisnani, H. (2020). Optimalisasi Peran Pengawasan Orang Tua Dalam Pelaksanaan Sekolah Online Di Masa Pandemi COVID-19. Prosiding Penelitian \& Pengabdian Kepada Masyarakat, 7(1), 48-59.

Wiryanto. (2020). Proses Pembelajaran Matematika Di Sekolah Dasar Di Tengah Pandemi COVID-19. Jurnal Review Pendidikan Dasar, 6(2). 